\title{
Effect of Currency Exchange Rate on Economic Growth —Research Based on RMB Exchange Rate of VAR Model
}

\author{
Ren Yinghua ${ }^{1, a}$ Yang Yan ${ }^{2, b} \quad *$ Zhong Xiong ${ }^{3, c}$ \\ ${ }^{1,2}$ College of Finance and Statistics,Hunan University, Changsha, Hunan 410000, China \\ ${ }^{3}$ Finance Academy of Guangzhou University, Guangzhou, Guangdong 510006, China \\ a,b,c1144280865@qq.com
}

Keywords: international trade; economic growth; VAR model; RMB exchange rate; research

\begin{abstract}
Therefore, it is becomes increasingly important to make research on effect and function of exchange rate change on national economy, this paper uses effect of RMB exchange rate on important and export trade of China as research object, it further discusses its effect on economic growth, it uses case to analyze relations of economic condition, RMB exchange rate and trade condition of China by constructing import and export VAR model, so that it is convenient for use to learn its effect on economic growth of China, which has certain realistic meanings and scholar research values.
\end{abstract}

\section{Introduction}

As the comprehensive price index for one nation to carry out international economic activity, RMB exchange rate implements function of price changeover in international finance and international trade, so that it becomes to be the important lever to adjust economic operation of one nation. Its change has profound effect on foreign trade balance and domestic economic activity, so it can be said that a slight move in one part may affect the situation as a whole. With the increase of economic integration between China and the world, effect of RMB exchange rate becomes increasingly obvious and complicated on economic operation. Therefore, it is very important to make research on effect of exchange rate change on economic effect and function of one nation, international trade has become to be the important growth point of Chinese economy, it has certain scholar values and realistic meanings. This paper just uses this as start point to analyze relations of economic condition, RMB exchange rate and trade condition in China is by constructing import and export VAR model of China, so that it is convenient for us to make research on effect of RMB exchange rate change on economic growth in China.

\section{Evolution process and characteristic of Chinese exchange rate system}

For a long time, China has been always implemented floating exchange rate system, since the opening-up and reform in the 1970s, RMB exchange rate system has made continual deepening reform, which has mainly undergone 6 stages, RMB exchange rate in different stages have different policy target, characteristic and exchange rate level, the details are indicated by the following table:

Table 1 Reform Process of Chinese EMB Exchange Rate System

\begin{tabular}{|l|l|l|l|}
\hline \multicolumn{1}{|c|}{$\begin{array}{l}\text { Reform } \\
\text { process }\end{array}$} & \multicolumn{1}{|c|}{ Policy target } & \multicolumn{1}{c|}{ Characteristic } \\
\hline $\begin{array}{l}\text { From } 1973 \text { to } \\
1980\end{array}$ & $\begin{array}{l}\text { Stabilize exchange rate, } \\
\text { reduce effect of international } \\
\text { exchange rate on Chinese } \\
\text { currency }\end{array}$ & $\begin{array}{l}\text { Watch on a cluster of } \\
\text { floating exchange rate } \\
\text { system of currency }\end{array}$ & Relatively stable \\
\hline $\begin{array}{l}\text { From } 1981 \text { to } \\
1984\end{array}$ & $\begin{array}{l}\text { Promote import and export } \\
\text { exchange-earning in foreign } \\
\text { enterprise }\end{array}$ & $\begin{array}{l}\text { Internal settlement price of } \\
\text { Official exchange rate and } \\
\text { trade foreign exchange are } \\
\text { coexist }\end{array}$ & Slight decrease \\
\hline From & Keep international revenue & Official exchange rate and & Official exchange rate \\
\hline
\end{tabular}




\begin{tabular}{|l|l|l|l|}
\hline $\begin{array}{l}1985 \text { to } \\
1993\end{array}$ & $\begin{array}{l}\text { and expenditure balance, } \\
\text { promote export } \\
\text { exchange-earning of foreign } \\
\text { enterprise }\end{array}$ & $\begin{array}{l}\text { adjustment price of foreign } \\
\text { exchange are coexist }\end{array}$ & $\begin{array}{l}\text { is always decreasing } \\
\text { by way of one-step } \\
\text { process, but stability is } \\
\text { normal state }\end{array}$ \\
\hline $\begin{array}{l}\text { From } \\
2094 \text { to }\end{array}$ & $\begin{array}{l}\text { Maintain stabilization of } \\
\text { exchange rate, stabilize } \\
\text { currency value and promote } \\
\text { economic development }\end{array}$ & $\begin{array}{l}\text { Single and managed floating } \\
\text { exchange rate based on } \\
\text { market }\end{array}$ & $\begin{array}{l}\text { Exchange rate has } \\
\text { stability and } \\
\text { enhancement }\end{array}$ \\
\hline $\begin{array}{l}\text { From } 2005 \text { to } \\
2009\end{array}$ & $\begin{array}{l}\text { Balance international revenue } \\
\text { and expenditure, avoid } \\
\text { restriction of currency policy } \\
\text { and promote economic } \\
\text { development }\end{array}$ & $\begin{array}{l}\text { Floating exchange rate } \\
\text { system based on market and } \\
\text { refers to a cluster of } \\
\text { currency to make adjustment } \\
\text { and management. }\end{array}$ & $\begin{array}{l}\text { Expectation of } \\
\text { exchange rate } \\
\text { appreciation increases, } \\
\text { trade surplus } \\
\text { continually expanding, } \\
\text { and currency system } \\
\text { becomes increasingly } \\
\text { passive. }\end{array}$ \\
\hline $\begin{array}{l}\text { From } \\
\text { to now } \\
\text { to now }\end{array}$ & $\begin{array}{l}\text { Balance international revenue } \\
\text { and expenditure, promote } \\
\text { economic development }\end{array}$ & $\begin{array}{l}\text { Managed floating exchange } \\
\text { rate system, intensify } \\
\text { flexibility of RMB exchange } \\
\text { rate. }\end{array}$ & $\begin{array}{l}\text { Exchange rate quickly } \\
\text { increases. }\end{array}$ \\
\hline
\end{tabular}

\section{Effect of RMB Exchange Rate on Import and Export in China}

By the year of 2010, China has becomes to the largest export trade nation and the second largest import trade nation, the import and export amount respectively accounts for $10.4 \%$ and $9.1 \%$ in the world trade amount, While theory of exchange rate change can be traced back to mercantilist Thomas. Meng, who thinks that trade balance and exchange rate have relations of mutual effect, trade surplus will make exported goods price increase and imported goods price decrease, so that it reduces export and increases import, which will make trade surplus transfer to trade deficit. From the above we can see that import and export in China account for larger percentage in total production amount, economic growth will be certainly affected by RMB exchange rate change. In order to use demonstration research to analyze effect of exchange rate change on trade, economic growth, we mostly make analysis by VAR model.

\section{Establishment and Estimation of VAR Model}

Effect VAR model constructed by this paper on effect of RMB exchange rate on international trade of China includes 3 variables such as exchange rate, economic condition in China, trade conditions, its simplified form of model is as follows:

$$
Z_{t}=\sum_{i=1}^{P} \Phi_{i Z_{t-i}}+H w_{t}+v_{t}
$$

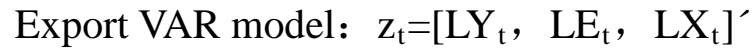

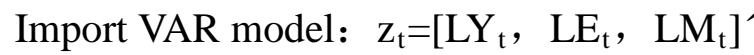

Of which, $\mathrm{X}_{\mathrm{t}}$ indicates the total of export, $\mathrm{M}_{\mathrm{t}}$ indicates the total of import, because variable of trade condition has difference, the meanings indicated by $\mathrm{z}_{\mathrm{t}}$ is also different as for different VAR model. $E_{t}$ represents exchange rate of RMB exchanged to SDR (Special Drawing Rights), we choose RMB to exchange SDR exchange rate just because this exchange rate can effectively reflect international value of RMB, it is superior to exchange rate of RMB to exchange US dollar in completeness and accuracy. $\mathrm{Y}_{\mathrm{t}}$ indicates GDP of China, it is used to reflect the general conditions of Chinese economy. According to requirement of model estimation, it needs to make difference transformation on formula (1) and gets formula (2): 


$$
\Delta z_{t}=\Pi z_{t-1}+\sum_{i=1}^{P-1} \Gamma_{i} \Delta z_{t-i}+H w_{t}+v_{t}
$$

Here, $\Pi=\sum_{i=1}^{P} \Phi_{i}-\mathrm{I}$, while $\Gamma_{i}=-\sum_{j=i+1}^{P} \Phi j$, because $\Delta z_{t-i}$ is the vector composed by I ( 0 ) variable, so only when $\Pi z_{t-1}$ is vector of $\mathrm{I}(0)$, which means variables $\mathrm{z}_{1, \mathrm{t}-1}, \mathrm{z}_{2, \mathrm{t}-1}, \mathrm{z}_{3, \mathrm{t}-1} \ldots \mathrm{z}_{\mathrm{q}, \mathrm{t}-1}$ have co-integration relations, we can regard $\Delta z_{t}$ is the smooth and stable process, the co-integration relations of the above-mentioned variables is mainly depend on sequence $\mathrm{r}$ of matrix.

Of course, we need to make further test on the original variable, we adopt method of co-integration test by Johansen to carry put, test result indicates that there is no co-integration relations among original variables, so this paper uses geometrical difference sequencing of variables to establish VAR model. Firstly, we make test on stability of established model, test result is indicated by diagram 1 .

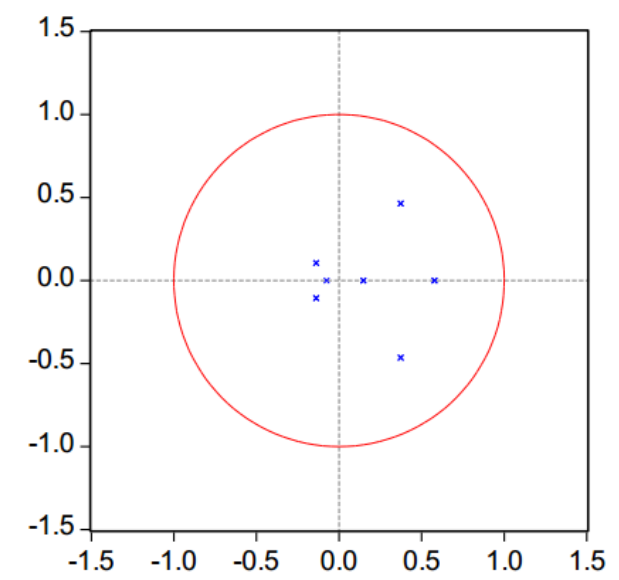

Diagram 1 Stability test of VAR model

According to test result on stability in the above diagram, 7 characteristics of VAR model are all within the unit circle, so this model is stable, which can carry out the subsequent impulse response analysis, result obtained from impulse response function is effective and stable.

The data required by model on import and export amount in China comes from data base of WIND information, monthly data of industrial production index and monthly average value of RMB to exchange SDR exchange rate are all from international financial statistic data based of IMF. We use ADF unit root to test smoothness of each variable, guarantee model variable is in the same order and single complete, time order data of test result are all 1 , and the detailed structure is indicated by the following diagram:

Table 2 Test result of ADF unit root

\begin{tabular}{|l|l|l|l|l|}
\hline Test condition & LX & LM & LY & LE \\
\hline $\begin{array}{l}\text { include constant, exclude } \\
\text { time trend item }\end{array}$ & -0.6818 & -0.9461 & -0.9300 & -1.2127 \\
\hline $\begin{array}{l}\text { include constant and time } \\
\text { trend item }\end{array}$ & $\left.-2.19435^{*}\right)$ & $\left(-8.0094^{*}\right)$ & $\left(-7.7560^{*}\right)$ & $\left(-6.2765^{*}\right)$ \\
\hline
\end{tabular}

In addition, the optimal delay order of import and export VAR model are all 4, coupled with test of vector error rectification model, it uses 1 order difference form to make reconstruction on each variable of long-time relation model and regards residual error in the long-time relation model as explanation variable, introduces into short-time dynamic relation model, gradually eliminates indistinctive items in the model and finally confirms the optimal model form. 


\section{Analysis on Impulse Response Function}

Analysis method on IRF can be used to describe the impulse and reaction caused by one error item of endogenous variable, which implements attack of one standard error on the random error item and produces effect on current value and future value of endogenous variable. Here, we adopt Generalized Impulse Response Function put forward by Koop, Pesaran and Potter in 1996 to analyze dynamic effect caused by impact of one variable on other variables and complete model, so that it explains dynamic relations among each variable, IMF can avoid problems of decomposition order setting of Cholesky and guarantees accuracy of analysis result. This paper adopts variance decomposition to analyze contribution of impact of one variable on the other variable. We can identify effect of new information impact on trade condition change caused by exchange rate change of one standard difference, economic change condition and trade change through general IMF. The analysis result of general IMF and variance decomposition on import and export VAR model is indicated by diagram 3 and 4 :
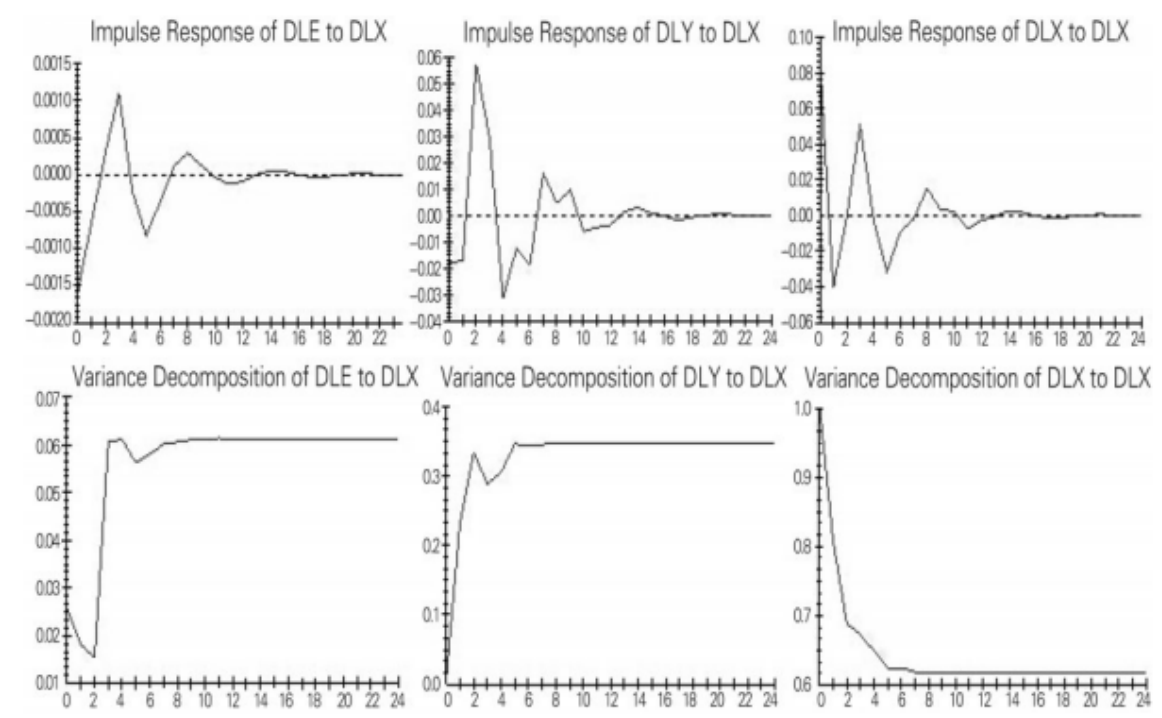

Diagram 2 Analysis result on general IMF and variance decomposition of export VAR model
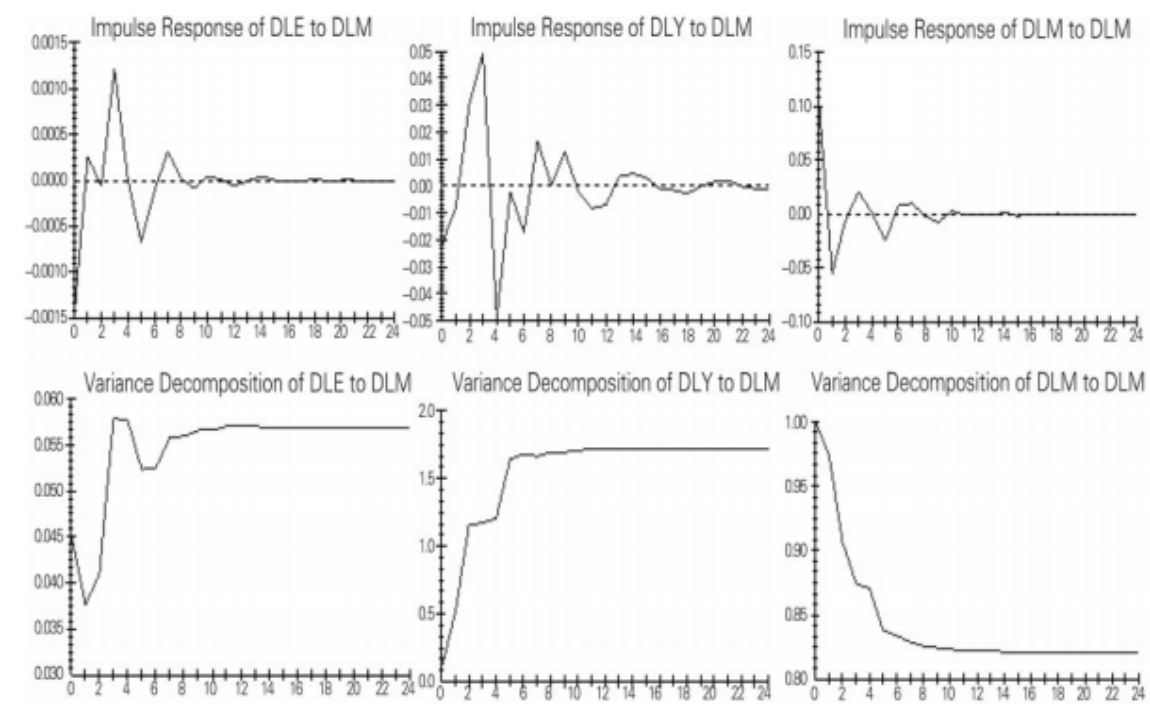

Diagram 3 Analysis result on general IMF and variance decomposition of import VAR model

From diagram 2 we can see that DLX starts to have positive reaction on impact of 1 standard difference information of DLE, and then the effect gradually reduces which appears 4 times shock in the past 12 months and finally tends to be stable. Exchange rate change has little effect on export trade amount, exchange rate change in 1 unit can only reverse effect on export of about 0.0015 unit, 
exchange rate has little contribution on export effect, which can explain 6.1\% change in export and it has obvious delay effect, the effect will tends to be stable after 8 months.

Therefore, we think RMB exchange rate change will produce obvious effect on export trade in China, but we can not deny that this effect is still exists in little range. Secondly, the economic condition change in China has promotion effect on export trade change, but it has hysteresis and starts to appear after 2 months, the impact of DLF in one standard difference can mostly produce change in export trade of about $0.058 \%$, the contribution on export trade change keeps at $34.7 \%$ after 5 months. Thirdly, export trade change is caused by itself, which has higher contribution on self change and keeps at $62 \%$ after 4 months.

From the above diagram 3, we can see analysis result of import VAR model is similar to that export VAR. Firstly, RMB exchange rate change will have obvious effect on import trade, exchange rate change impact of 1 standard difference can mostly cause effect on import trade of 0.0018 unit, it is reversed in the beginning and then appears weak shock, then it tends to be stable after 12 months, the contribution is about $5.7 \%$. Secondly, impact of economic condition change in China has certain effect on import trade change, economic condition impact of 1 standard difference will produce import amount effect of about 0.05 unit, the contribution tends to be stable after 6 months and it is about $17 \%$. Thirdly, import trade change is mainly caused by self fluctuation; contribution is maintained at $82 \%$ or so after 6 months.

\section{Conclusion}

In a word, international import and export trade is one of the important parts of economic growth in China. According to the constructed import and export VAR model, analysis, we find that RMB exchange rate change has little effect on import and export trade amount, exchange rate change of 1 unit will cause reverse effect on export amount of about 0.0015 unit, while import amount only has effect of 0.0018 unit. But we can not deny that RMB exchange rate change has certain effect on trade import and export in China, from this we can see RMB exchange rate change has certain effect on economic growth, especially RMB exchange rate change has concretionary effect on output in the short time, for example, import reduces, actual GDP decreases, family consumption and savings reduce, and employment level also decreases, it is positive effect in the middle and long time. Import, customs, government savings and income present positive effect under effect of RMB appreciation; domestic output will stimulate appreciation of exchange rate. China should make active, gradual adjustment on RMB exchange rate according to real conditions of economic development, use RMB exchange rate change as opportunity to promote exchangeable RMB fund project, accelerate foreign exchange market construction, complete updating of industrial structure, optimize Chinese economic structure and promote persistent, healthy economic growth.

\section{Knowledgements}

National Social Science Fund Project RMB internationalization statistical monitoring research (15BTJ009)

China Postdoctoral special funding project (2015T80865)

Guangzhou International Finance Research Institute strategic research Research on the process o f RMB internationalization and Path Innovation (GF1151A02)

\section{References}

[1]Bhattacharya, Karayalcin,Thomakos. Exchange Rates Pass-Through and Relative Prices: An Industry-Level Empirical Investigation[J].Journal of International Money and Finance, 2010: 12-17

[2]Han Xue. Effect of RMB Exchange Rate Fluctuation on Economy in China: Theory and Demonstration Analysis [D]. Master Thesis of Jilin University, 2011: 50-51

[3]Shi Linmei. Demonstration Analysis on Effect of RMB Exchange Rate Fluctuation on Aggregate 
Demand of Chinese Economy. Master Thesis of Jilin University, 2014:17

[4]Michael B.Devereux, Charles Engel.Monetary policy in the open

economy revisited: price setting and Exchange-rate flexibility[J].

Review of Economic Studies, 2003,70 (4) : 765-783

[5]Zhu Shanshan. Effect Research of RMB Exchange Rate Change Based on VAR Model on Inflation in China [D].Master Thesis of Hunan University, 2012: 18-19

[6]Yang Kaiwen, Zang Rihong. VAR Model Demonstration Analysis of RMB Exchange Rate Change on Chinese International Trade [J]. Finance Theory and Practice, 2014 (12) : 20-25

[7]Crosby.M.Exchange Rate Volatility and Macroeconomic Performance in Hong Kong[R].Hong Kong: Institute for Monetary, 2000:2-5

[8]Liu Ali. Research on Effect of RMB Exchange Rate Based on VAR Model on Economic Growth [D].Master Thesis of Southwest JiaoTong University, 2011: 28

[9]Gao Weigang, Lan Tian. Demonstration Research on Effect of RMB Actual Exchange Rate on Import and Export Trade of China and America_-Analysis Based on VAR Model and VEC Model [J].Modern Management Science, 2013 (3) : 59-61,112

[10]Hao Dan. Analysis on Trade Price Transmission by RMB Exchange Rate Fluctuation [J].Chinese E-business, 2013 (14) : 230-231

[11]Liu Ali. Demonstration Research of RMB Exchange Rate Effect Based on VAR Model on Foreign Trade [J].Goods and Quality. Scholar Observation, 2013(11): 2,28,53

[12]Shan Dan. Transmission Effect Research of RMB Exchange Rate Fluctuation on Inflation [D].Master Thesis of Jilin University of Finance and Economics , 2012: 31 